\title{
Paenibacillus cellulosilyticus sp. nov., a cellulolytic and xylanolytic bacterium isolated from the bract phyllosphere of Phoenix dactylifera
}

\author{
Raúl Rivas,† Paula García-Fraile, Pedro F. Mateos, \\ Eustoquio Martínez-Molina and Encarna Velázquez \\ Departamento de Microbiología y Genética, Edificio Departamental, Campus Miguel de \\ Unamuno, Universidad de Salamanca, 37007 Salamanca, Spain
}

Correspondence

Raúl Rivas

raul@wwwedu-micro.usal.es

\begin{abstract}
A bacterial strain designated PALXIL08 ${ }^{\top}$ was isolated from the phyllosphere of Phoenix dactylifera bracts. A phylogenetic analysis based on the 16S rRNA gene sequence placed the isolate within the genus Paenibacillus in the same subgroup as Paenibacillus kobensis and Paenibacillus curdlanolyticus (98.9 and $97.9 \%$ sequence similarity, respectively). The DNA hybridization values between the isolate and the type strains of Paenibacillus kobensis and Paenibacillus curdlanolyticus were found to be $27 \cdot 4$ and $17 \cdot 6 \%$, respectively. The isolate comprised Gramvariable, facultatively anaerobic, motile, sporulating rods. Catalase and oxidase were produced and cellulose, xylan, starch and aesculin were hydrolysed. Many carbohydrates served as carbon sources for growth. MK-7 was the predominant menaquinone, and anteiso- $C_{15: 0}$ and iso- $C_{16: 0}$ were the major fatty acids. The DNA G $+\mathrm{C}$ content was $51 \mathrm{~mol} \%$. DNA relatedness data and the results of phylogenetic and phenotypic analyses showed that strain PALXIL08 ${ }^{\top}$ should be considered as the type strain of a novel species of the genus Paenibacillus, for which the name Paenibacillus cellulosilyticus sp. nov. is proposed. The type strain is PALXIL08 ${ }^{\top}$ (=LMG $22232^{\top}=$ CECT $5696^{\top}$ ).
\end{abstract}

Cellulose and xylan are the most abundant polysaccharides in plant cell walls. Several members of the genus Paenibacillus excrete diverse assortments of extracellular polysaccharidehydrolysing enzymes, including cellulases and xylanases (Zamost et al., 1991; Morales et al., 1995; Hespell, 1996; Nielsen \& Sorensen, 1997; Ay et al., 1998; Lee et al., 2000; Sánchez et al., 2003; Velázquez et al., 2004; Rivas et al., 2005a, b). Paenibacillus species capable of hydrolysing vegetal polymers have been frequently isolated from soil and plant related sources, and a species has been isolated from the phyllosphere (Rivas et al., 2005b). This ecosystem is colonized by complex microbial populations; nevertheless, most species present in the phyllosphere remain undescribed because they have not been isolated in pure culture (Yang et al., 2001). In the present work, we describe the isolation and identification of a novel xylan-degrading bacterium from the bract phyllosphere of Phoenix dactylifera.

tPresent address: Laboratorium voor Microbiologie, Vakgroep Biochemie, Fysiologie en Microbiologie, Universiteit Gent, K. L. Ledeganckstraat 35, B-9000 Gent, Belgium.

The GenBank/EMBL/DDBJ accession number for the 16S rRNA gene sequence of strain PALXIL08 ${ }^{\top}$ is DQ407282.

An expanded phylogenetic tree for strain PALXILO8 ${ }^{\top}$ and representative strains of the genus Paenibacillus is available as a supplementary figure in IJSEM Online.
Strain PALXIL08 ${ }^{\mathrm{T}}$ was isolated as described previously (Rivas et al., 2005b) on XED medium (xylan, $0 \cdot 7 \%$; yeast extract, $0 \cdot 3 \%$; agar, $2 \cdot 5 \%$, w/v) after 7 days incubation at $28{ }^{\circ} \mathrm{C}$ and a pure culture was maintained in a glycerol suspension $(25 \%, \mathrm{v} / \mathrm{v})$ at $-80{ }^{\circ} \mathrm{C}$.

Strain PALXIL08 ${ }^{\mathrm{T}}$ was grown in nutrient agar for $48 \mathrm{~h}$ to check for motility by phase-contrast microscopy with the hanging drop method. Gram staining was carried out by using the procedure described by Doetsch (1981). The flagellation type was determined by electron microscopy after $48 \mathrm{~h}$ incubation of strain PALXIL08 ${ }^{\mathrm{T}}$ in nutrient agar at $22^{\circ} \mathrm{C}$. The cells were gently suspended in sterile water and then stained with $0.2 \%$ uranyl acetate and examined at $80 \mathrm{kV}$ with a Zeiss EM 209 transmission electron microscope. Strain PALXIL08 ${ }^{\mathrm{T}}$ was found to be Gram-variable and motile by means of peritrichous flagella.

For sequencing of the 16S rRNA gene, DNA extraction was carried out as described previously (Rivas et al., 2001). Amplification and sequencing of the 16S rRNA gene were performed using a previously described method (Rivas et al., 2003). An almost-complete $16 \mathrm{~S}$ rRNA gene sequence was obtained and compared with those deposited in databases. Sequences were aligned using CLUSTAL $\mathrm{X}$ software (Thompson et al., 1997). Distances were calculated according to the models of Jukes \& Cantor (1969), Kimura (1980), 


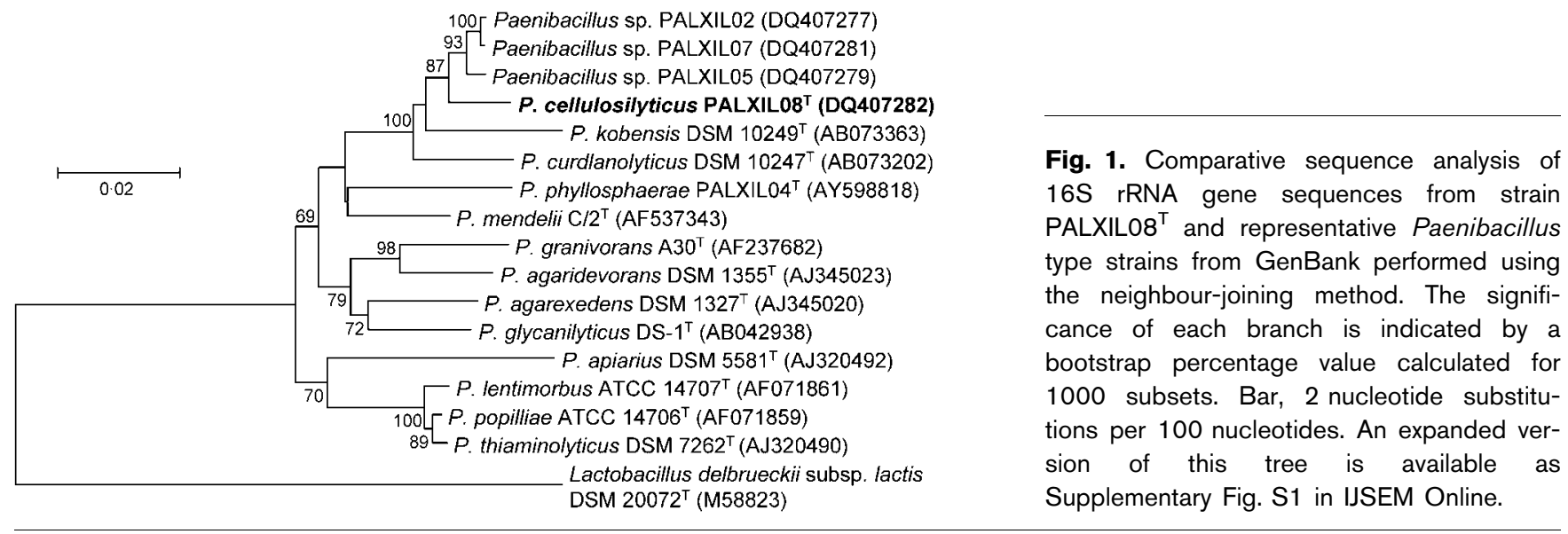

Tajima \& Nei (1984) and Tamura \& Nei (1993). Phylogenetic trees were inferred using the neighbourjoining method (Saitou \& Nei, 1987), minimum evolution (Rzhetsky \& Nei, 1993) and parsimony analysis (Felsenstein, 1983). Bootstrap analysis was based on 1000 resamplings. The MEGA2 package (Kumar et al., 2001) was used for all analyses. As no significant topological differences were found among the phylogenetic trees obtained by the different methods used, only those trees constructed by using the Kimura model and the neighbour-joining method are shown. Comparison of the almost-complete $16 \mathrm{~S}$ rRNA gene sequence of strain PALXIL $08^{\mathrm{T}}$ with sequences held in GenBank indicated that this organism is phylogenetically related to members of the genus Paenibacillus. Fig. 1 shows the phylogenetic tree obtained with the neighbour-joining method (an expanded tree is available as Supplementary Fig. S1 in IJSEM Online). The most closely related type strains are Paenibacillus kobensis DSM $10249^{\mathrm{T}}$ and Paenibacillus curdlanolyticus DSM $10247^{\mathrm{T}}(98 \cdot 9$ and 97.9\% sequence similarity, respectively). We included strains PALXIL02, PALXIL05 and PALXIL07 in the phylogenetic analysis because they were isolated from the same ecosystem, and because they belong to the same group, on the basis of $16 \mathrm{~S}$ rRNA gene sequences. However, preliminary data on hybridization between strain PALXIL08 $^{\mathrm{T}}$ and strains PALXIL02, PALXIL05 and PALXIL07 produced values below $30 \%$.

Isolate PALXIL08 ${ }^{\mathrm{T}}$ was cultivated in TSB (Becton Dickinson, BBL) for $24 \mathrm{~h}$ at $28^{\circ} \mathrm{C}$ in a rotary shaker (90 r.p.m.) for menaquinone analyses using freeze-dried cells. The same medium amended with $15 \mathrm{~g}$ agar $\mathrm{l}^{-1}$ was used to cultivate the strain for examination of the fatty acid composition. The menaquinone and cellular fatty acid compositions were analysed as described by Zimmermann et al. (1998). An unsaturated menaquinone with seven isoprene units (MK-7) was the predominant isoprenoid quinone found in strain PALXIL0 $8^{\mathrm{T}}$. The major cellular fatty acid in strain PALXIL08 ${ }^{\mathrm{T}}$, Paenibacillus curdlanolyticus and Paenibacillus kobensis was anteiso-branched $\mathrm{C}_{15: 0}$ (see Table 1), which is the dominant cellular fatty acid in all members of the genus Paenibacillus (Shida et al., 1997b).
The fatty acid profile of PALXIL08 ${ }^{\mathrm{T}}$ was similar to those of the type strains of related Paenibacillus species (Shida et al., 1997a), but it differed in the proportions of some fatty acids. The main differences with respect to the most closely related species were in the amounts of iso- $\mathrm{C}_{16: 0}$, iso- $\mathrm{C}_{15: 0}$, iso$\mathrm{C}_{17: 0}, \mathrm{C}_{16: 0}$ and anteiso- $\mathrm{C}_{17: 0}$ (for the novel isolate and Paenibacillus kobensis) and the amounts of iso- $\mathrm{C}_{16: 0}$, iso$\mathrm{C}_{17: 0}, \mathrm{C}_{16: 0}, \mathrm{C}_{17: 0}$ and anteiso- $\mathrm{C}_{17: 0}$ (for the novel isolate and Paenibacillus curdlanolyticus).

DNA for the determination of the $\mathrm{G}+\mathrm{C}$ content was prepared according to Chun \& Goodfellow (1995). The

Table 1. Cellular fatty acid composition of strain PALXIL08 ${ }^{\top}$ and phylogenetically related species

Taxa: strain PALXIL08 ${ }^{\mathrm{T}}$ (data from this study); 2, Paenibacillus kobensis (Dasman et al., 2002); 3, Paenibacillus curdlanolyticus (Dasman et al., 2002); 4, Paenibacillus phyllosphaerae (Rivas et al., 2005b); 5, Paenibacillus mendelii (Šmerda et al., 2005). Values are percentages of total fatty acids; fatty acids detected in amounts of less than $1 \%$ in all five taxa are not shown. ND, Not detected.

\begin{tabular}{|lrrrrr|}
\hline Fatty acid & $\mathbf{1}$ & $\mathbf{2}$ & $\mathbf{3}$ & $\mathbf{4}$ & $\mathbf{5}$ \\
\hline Saturated straight-chain & & & & & \\
$\mathrm{C}_{14: 0}$ & $1 \cdot 3$ & $1 \cdot 2$ & $0 \cdot 8$ & $1 \cdot 8$ & $1 \cdot 2$ \\
$\mathrm{C}_{15: 0}$ & $\mathrm{ND}$ & $0 \cdot 9$ & $0 \cdot 4$ & $\mathrm{ND}$ & $6 \cdot 1$ \\
$\mathrm{C}_{16: 0}$ & $7 \cdot 4$ & $16 \cdot 1$ & $0 \cdot 6$ & $11 \cdot 8$ & $5 \cdot 9$ \\
$\mathrm{C}_{17: 0}$ & $0 \cdot 4$ & $0 \cdot 2$ & $9 \cdot 9$ & $0 \cdot 6$ & $1 \cdot 0$ \\
Saturated iso-branched & & & & & \\
$\mathrm{C}_{14: 0}$ & $3 \cdot 0$ & $2 \cdot 3$ & $1 \cdot 8$ & $2 \cdot 2$ & $1 \cdot 3$ \\
$\mathrm{C}_{15: 0}$ & $3 \cdot 3$ & $6 \cdot 1$ & $5 \cdot 4$ & $9 \cdot 9$ & $13 \cdot 5$ \\
$\mathrm{C}_{16: 0}$ & $28 \cdot 8$ & $14 \cdot 5$ & $15 \cdot 4$ & $11 \cdot 1$ & $11 \cdot 4$ \\
$\mathrm{C}_{17: 0}$ & $1 \cdot 6$ & $5 \cdot 2$ & $16 \cdot 4$ & $3 \cdot 3$ & $6 \cdot 1$ \\
Saturated anteiso-branched & & & & & \\
$\mathrm{C}_{15: 0}$ & $44 \cdot 1$ & $38 \cdot 5$ & $44 \cdot 6$ & $48 \cdot 6$ & $45 \cdot 6$ \\
$\mathrm{C}_{17: 0}$ & $8 \cdot 3$ & $14 \cdot 0$ & $4 \cdot 7$ & $6 \cdot 4$ & $7 \cdot 1$ \\
Unsaturated & & & & & \\
$\mathrm{C}_{16: 1} \omega 7 c$ & $0 \cdot 5$ & $\mathrm{ND}$ & $\mathrm{ND}$ & $1 \cdot 9$ & $\mathrm{ND}$ \\
$\mathrm{C}_{16: 1} \omega 11 c$ & $\mathrm{ND}$ & $\mathrm{ND}$ & $\mathrm{ND}$ & $1 \cdot 4$ & $0 \cdot 8$ \\
\hline
\end{tabular}


value for strain PALXIL08 ${ }^{\mathrm{T}}$ was determined using the thermal denaturation method (Mandel \& Marmur, 1968) and was found to be $51 \mathrm{~mol} \%$, which is similar to those obtained for Paenibacillus curdlanolyticus and Paenibacillus kobensis (Shida et al., 1997a).

DNA-DNA hybridization was carried out as described by De Ley et al. (1970), with the modifications described by Huß et al. (1983) and Escara \& Hutton (1980). DNA was isolated as described by Cashion et al. (1977). The DNA relatedness values for strain PALXIL08 ${ }^{\mathrm{T}}$ versus Paenibacillus kobensis DSM $10249^{\mathrm{T}}$ and Paenibacillus curdlanolyticus DSM $10247^{\mathrm{T}}$ were $27 \cdot 4$ and $17 \cdot 6 \%$; respectively; this suggested that the novel isolate was not closely related to the known species, according to the current concept of bacterial species (Wayne et al., 1987).

Phenotypic characterization was performed according to the standard methods described by Claus \& Berkeley (1986) and Logan \& Berkeley (1984) and by using the API 20NE and API 20E systems (bioMérieux) according to the manufacturer's instructions. Acid production from glucose, xylose, mannitol and L-arabinose, gas production from glucose, acetoin production, the ability to grow in the presence of 2,5 and $7 \% \mathrm{NaCl}$, nitrate reduction, anaerobic growth, and phenylalanine deaminase, catalase, caseinase and oxidase activities were analysed as described by Claus \& Berkeley (1986). Amylases and cellulases were analysed as described previously (Rivas et al., 2003). Growth at temperatures ranging from 4 to $45^{\circ} \mathrm{C}$ was determined in YED medium $(0.5 \%$ yeast extract, $0.7 \%$ glucose and $2 \%$ agar). Growth at $\mathrm{pH} 5 \cdot 7$ and $6 \cdot 8$ was tested as described by Claus \& Berkeley (1986), growth at $\mathrm{pH} 7-8$ was tested in YED medium containing $100 \mathrm{mM} \mathrm{Na}_{2} \mathrm{HPO}_{4} /$ $\mathrm{NaH}_{2} \mathrm{PO}_{4}$ and growth at $\mathrm{pH} 9$ and 10 was tested in the same medium containing $100 \mathrm{mM} \mathrm{NaHCO} / \mathrm{Na}_{2} \mathrm{CO}_{3}$. The differentiating characteristics of strain PALXIL08 ${ }^{\mathrm{T}}$ and phylogenetically related species are shown in Table 2 . The other characteristics determined are given in the species description. Strain PALXIL08 ${ }^{\mathrm{T}}$ differs from both Paenibacillus kobensis and Paenibacillus curdlanolyticus in terms of nitrate reduction, oxidase, acetylmethylcarbinol and cellulase production and assimilation of mannose, rhamnose and $\mathrm{N}$-acetylglucosamine. It also differs from Paenibacillus kobensis in terms of acid production from raffinose.

On the basis of the phylogenetic, chemotaxonomic and phenotypic data, we propose that isolate PALXIL08 ${ }^{\mathrm{T}}$ $\left(=\mathrm{LMG} 22232^{\mathrm{T}}=\right.$ CECT $\left.5696^{\mathrm{T}}\right)$ represents a novel species of the genus Paenibacillus, for which the name Paenibacillus cellulosilyticus sp. nov. is proposed.

\section{Description of Paenibacillus cellulosilyticus sp. nov.}

Paenibacillus cellulosilyticus (cel.lu.lo.si.ly'ti.cus. N.L. n. cellulosum cellulose; Gr. adj. lutikos able to loose, able to
Table 2. Distinctive phenotypic characteristics of strain PALXILO8 ${ }^{\top}$ and phylogenetically related type strains

Strains: 1, strain PALXIL08 ${ }^{\mathrm{T}}$ (data from this study); 2, Paenibacillus kobensis IFO $15729^{\mathrm{T}}$ (Kanzawa et al., 1995; Dasman et al., 2002); 3, Paenibacillus curdlanolyticus IFO $15724^{\mathrm{T}}$ (Kanzawa et al., 1995; Dasman et al., 2002); 4, Paenibacillus phyllosphaerae PALXIL04 $^{\mathrm{T}}$ (Rivas et al., 2005b); 5, Paenibacillus mendelii $\mathrm{C} / 2^{\mathrm{T}}$ (Šmerda et al., 2005). +, Positive; -, negative; V, variable; W, weak; ND, no data available.

\begin{tabular}{|lccccc|}
\hline Characteristic & $\mathbf{1}$ & $\mathbf{2}$ & $\mathbf{3}$ & $\mathbf{4}$ & $\mathbf{5}$ \\
\hline Oxidase & + & - & - & + & + \\
Nitrate reduction & - & + & + & + & - \\
Production of: & & & & & \\
$\quad$ Acetoin & + & - & - & - & $\mathrm{ND}$ \\
$\quad$ Cellulases on CM-cellulose & + & - & - & + & $\mathrm{ND}$ \\
Acid from raffinose & + & - & + & + & + \\
Assimilation of: & & & & & \\
$\quad$ Mannose & + & - & - & $\mathrm{W}$ & - \\
$\quad$ Rhamnose & + & - & - & $\mathrm{W}$ & + \\
$\quad \mathrm{N}$-Acetylglucosamine & - & + & + & - & - \\
\end{tabular}

dissolve; N.L. adj. lyticus - $a$-um dissolving; N.L. masc. adj. cellulosilyticus cellulose-dissolving).

Spore-forming rods, $0 \cdot 8-0 \cdot 9 \mu \mathrm{m}$ wide and $4 \cdot 0-4 \cdot 2 \mu \mathrm{m}$ long. Gram-variable. Motile by means of peritrichous flagella. Ellipsoidal spores are formed in swollen sporangia and occupy a subterminal position in the cell. Aerobic or facultatively anaerobic, chemo-organotrophic and xylanolytic bacteria. Colonies on YED are circular, flat, white/ cream, opaque and usually $1-3 \mathrm{~mm}$ in diameter after $48 \mathrm{~h}$ at $28^{\circ} \mathrm{C}$. The major quinone is MK-7. Main fatty acids are anteiso- $\mathrm{C}_{15: 0}$ and iso- $\mathrm{C}_{16: 0}$. Growth occurs at $10-37^{\circ} \mathrm{C}$ (optimal growth occurs at $28^{\circ} \mathrm{C}$ ). Optimum pH is 7 . Oxidase- and catalase-positive. In Voges-Proskauer broth, the $\mathrm{pH}$ is $6 \cdot 5$. Acetoin is produced. Grows in the presence of $2 \% \mathrm{NaCl}$ but not in $5 \% \mathrm{NaCl}$. Nitrate is not reduced to nitrite. Negative for growth in anaerobic agar. Cellulases, xylanases, amylases and $\beta$-galactosidase are actively produced, but gelatinase, caseinase, arginine dihydrolase, indole, lysine decarboxylase, ornithine decarboxylase, urease, tryptophan deaminase, phenylalanine deaminase and hydrogen sulfide are not produced. Aesculin is hydrolysed. Gas is not produced from D-glucose. DGlucose, L-arabinose, mannose, maltose, xylose, rhamnose, sucrose, melibiose and gluconate are assimilated. Acid is produced from glucose, xylose, L-arabinose and raffinose. Negative for the assimilation of mannitol, inositol, sorbitol, $\mathrm{N}$-acetylglucosamine, amygdalin, caprate, propionate, adipate, malate, citrate and phenylacetate. The DNA G $+C$ content of the type strain is $51 \mathrm{~mol} \%$.

The type strain, PALXIL08 ${ }^{\mathrm{T}}\left(=\mathrm{LMG} 22232^{\mathrm{T}}=\mathrm{CECT}\right.$ $5696^{\mathrm{T}}$ ), was isolated from the bract phyllosphere of Phoenix dactylifera in Palma de Mallorca (Spain). 


\section{Acknowledgements}

This work was supported by the CAICYT-DGES and the JCyL (Spanish Government). We are grateful to the staff of the Deutsche Sammlung von Mikroorganismen und Zellkulturen (Braunschweig, Germany) for chemotaxonomic analyses. R. R. acknowledges a postdoctoral fellowship from Ministerio de Educación y Ciencia.

\section{References}

Ay, J., Goetz, F., Borriss, R. \& Heinemann, U. (1998). Structure and function of the Bacillus hybrid enzyme GluXyn-1: native-like jellyroll fold preserved after insertion of autonomous globular domain. Proc Natl Acad Sci U S A 95, 6613-6618.

Cashion, P., Holder-Franklin, M. A., McCully, J. \& Franklin, M. (1977). A rapid method for the base ratio determination of bacterial DNA. Anal Biochem 81, 461-466.

Chun, J. \& Goodfellow, M. (1995). A phylogenetic analysis of the genus Nocardia with 16S rRNA sequences. Int J Syst Bacteriol 45, 240-245.

Claus, D. \& Berkeley, R. C. W. (1986). Genus Bacillus Cohn 1872, $174^{\mathrm{AL}}$. In Bergey's Manual of Systematic Bacteriology, vol. 2, pp. 1105-1139. Edited by P. H. A. Sneath, N. S. Mair, M. E. Sharpe \& J. G. Holt. Baltimore: Williams \& Wilkins.

Dasman, Kajiyama, S., Kawasaki, H., Yagi, M., Seki, T., Fukusaki, E. \& Kobayashi, A. (2002). Paenibacillus glycanilyticus sp. nov., a novel species that degrades heteropolysaccharide produced by the cyanobacterium Nostoc commune. Int J Syst Evol Microbiol 52, 1669-1674.

De Ley, J., Cattoir, H. \& Reynaerts, A. (1970). The quantitative measurement of DNA hybridization from renaturation rates. Eur J Biochem 12, 133-142.

Doetsch, R. N. (1981). Determinative methods of light microscopy. In Manual of Methods for General Bacteriology, pp. 21-33. Edited by P. Gerhardt, R. G. E. Murray, R. N. Costilow, E. W. Nester, W. A. Wood, N. R. Krieg \& G. B. Phillips. Washington, DC: American Society for Microbiology.

Escara, J. F. \& Hutton, J. R. (1980). Thermal stability and renaturation of DNA in dimethyl sulfoxide solutions: acceleration of the renaturation rate. Biopolymers 19, 1315-1327.

Felsenstein, J. (1983). Parsimony in systematics: biological and statistical issues. Annu Rev Ecol Syst 14, 313-333.

Hespell, R. B. (1996). Fermentation of xylan, corn fiber, or sugars to acetoin and butanediol by Bacillus polymyxa strains. Curr Microbiol 32, 291-296.

Huß, V. A. R., Festl, H. \& Schleifer, K. H. (1983). Studies on the spectrometric determination of DNA hybridization from renaturation rates. Syst Appl Microbiol 4, 184-192.

Jukes, T. H. \& Cantor, C. R. (1969). Evolution of protein molecules. In Mammalian Protein Metabolism, pp. 21-132. Edited by H. N. Munro. London: Academic Press.

Kanzawa, Y., Harada, A., Takeuchi, M., Yolota, A. \& Harada, T. (1995). Bacillus curdlanolyticus sp. nov. and Bacillus kobensis sp. nov., which hydrolyze resistant curdlan. Int J Syst Bacteriol 45, 515-521.

Kimura, M. (1980). A simple method for estimating evolutionary rates of base substitutions through comparative studies of nucleotide sequences. J Mol Evol 16, 111-120.

Kumar, S., Tamura, K., Jakobsen, I. B. \& Nei, M. (2001). MEGA molecular evolutionary genetics analysis software. Tempe, AZ: Arizona State University.

Lee, H. J., Shin, D. J., Cho, N. C., Kim, H. O., Shin, S. Y., Im, S. Y., Lee, H. B., Chum, S. B. \& Bai, S. (2000). Cloning, expression and nucleotide sequences of two xylanase genes from Paenibacillus sp. Biotechnol Lett 22, 387-392.

Logan, N. A. \& Berkeley, R. C. W. (1984). Identification of Bacillus strains using the API system. J Gen Microbiol 130, 1871-1882.

Mandel, M. \& Marmur, J. (1968). Use of ultraviolet absorbance temperature profile for determining the guanine plus cytosine content of DNA. Methods Enzymol 12B, 195-206.

Morales, P., Madarro, A., Flors, A., Sendra, J. M. \& Pérez-González, J. A. (1995). Purification and characterization of a xylanase and an arabinofuranosidase from Bacillus polymyxa. Enzyme Microb Technol 17, 424-429.

Nielsen, P. \& Sorensen, J. (1997). Multi-target and mediumindependent fungal antagonism by hydrolytic enzymes in Paenibacillus polymyxa and Bacillus pumilus strains from barley rhizosphere. FEMS Microbiol Ecol 22, 183-192.

Rivas, R., Velázquez, E., Valverde, A., Mateos, P. F. \& MartínezMolina, E. (2001). A two primers random amplified polymorphic DNA procedure to obtain polymerase chain reaction fingerprints of bacterial species. Electrophoresis 22, 1086-1089.

Rivas, R., Sánchez, M., Trujillo, M. E., Zurdo-Piñeiro, J. L., Mateos, P. F., Martínez-Molina, E. \& Velázquez, E. (2003). Xylanimonas cellulosilytica gen. nov., sp. nov., a xylanolytic bacterium isolated from a decayed tree (Ulmus nigra). Int J Syst Evol Microbiol 53, 99-103.

Rivas, R., Mateos, P. F., Martínez-Molina, E. \& Velázquez, E. (2005a). Paenibacillus xylanilyticus sp. nov., an airborne xylanolytic bacterium. Int J Syst Evol Microbiol 55, 405-408.

Rivas, R., Mateos, P. F., Martínez-Molina, E. \& Velázquez, E. (2005b). Paenibacillus phyllosphaerae sp. nov., a xylanolytic bacterium isolated from the phyllosphere of Phoenix dactylifera. Int J Syst Evol Microbiol 55, 743-746.

Rzhetsky, A. \& Nei, M. (1993). Theoretical foundation of the minimum-evolution method of phylogenetic inference. Mol Biol Evol 10, 1073-1095.

Saitou, N. \& Nei, M. (1987). The neighbor-joining method: a new method for reconstructing phylogenetic trees. Mol Biol Evol 4, 406-425.

Sánchez, M. M., Pastor, F. I. \& Díaz, P. (2003). Exo-mode of action of cellobiohydrolase Cel48C from Paenibacillus sp. BP-23. A unique type of cellulase among Bacillales. Eur J Biochem 270, 2913-2919.

Shida, O., Takagi, H., Kadowaki, K., Nakamura, L. K. \& Komagata, K. (1997a). Transfer of Bacillus alginolyticus, Bacillus chondroitinus, Bacillus curdlanolyticus, Bacillus glucanolyticus, Bacillus kobensis, and Bacillus thiaminolyticus to the genus Paenibacillus and emended description of the genus Paenibacillus. Int J Syst Bacteriol 47, 289-298.

Shida, O., Takagi, H., Kadowaki, K., Nakamura, L. K. \& Komagata, K. (1997b). Emended description of Paenibacillus amylolyticus and description of Paenibacillus illinoisensis sp. nov. and Paenibacillus chibensis. Int J Syst Bacteriol 47, 299-306.

Šmerda, J., Sedláček, I., Páčová, Z., Durnová, E., Smíšková, A. \& Havel, L. (2005). Paenibacillus mendelii sp. nov., from surfacesterilized seeds of Pisum sativum L. Int J Syst Evol Microbiol 55, 2351-2354.

Tajima, F. \& Nei, M. (1984). Estimation of evolutionary distance between nucleotide sequences. Mol Biol Evol 1, 269-285.

Tamura, K. \& Nei, M. (1993). Estimation of the number of nucleotide substitutions in the control region of mitochondrial DNA in humans and chimpanzees. J Mol Evol 10, 512-526.

Thompson, J. D., Gibson, T. J., Plewniak, F., Jeanmougin, F. \& Higgins, D. G. (1997). The CLUSTAL_X windows interface: flexible strategies for multiple sequence alignment aided by quality analysis tools. Nucleic Acids Res 25, 4876-4882. 
Velázquez, E., de Miguel, T., Poza, M., Rivas, R., Rosselló-Mora, R. \& Villa, T. G. (2004). Paenibacillus favisporus sp. nov., a xylanolytic bacterium isolated from cow faeces. Int J Syst Evol Microbiol 54, 59-64.

Wayne, L. G., Brenner, D. J., Colwell, R. R. \& 9 other authors (1987). International Committee on Systematic Bacteriology. Report of the ad hoc committee on reconciliation of approaches to bacterial systematics. Int J Syst Bacteriol 37, 463-464.

Yang, C. H., Crowley, D. E., Borneman, J. \& Keen, N. T. (2001). Microbial phyllosphere populations are more complex than previously realized. Proc Natl Acad Sci $U$ S A 98, 3889-3894.

Zamost, B. L., Nielsen, H. K. \& Starnes, R. L. (1991). Thermostable enzymes for industrial applications. J Ind Microbiol 8, 71-82.

Zimmermann, O., Spröer, C., Kroppenstedt, R. M., Fuchs, E., Köchel, H. G. \& Funke, G. (1998). Corynebacterium thomssenii sp. nov., a Corynebacterium with $N$-acetyl- $\beta$-glucosaminidase activity from human clinical specimens. Int J Syst Bacteriol 48, 489-494. 